\title{
Novel near-infrared fluorescent probe for live cell imaging
}

\author{
MENG WAN, YUBING ZHU and JIANJUN ZOU \\ Department of Pharmacy, Nanjing First Hospital, Nanjing Medical University, Nanjing, Jiangsu 210006, P.R. China
}

Received March 28, 2018; Accepted November 6, 2019

DOI: $10.3892 /$ etm.2019.8323

\begin{abstract}
Near infrared (NIR) fluorescent probes play a crucial role in biological system imaging. A novel NIR fluorescent probe, IR787, was designed in the present study. Compared with indocyanine green (ICG), IR787 showed lower background fluorescent interference and higher fluorescence enhancement. Fluorescence intensities were detected by a Cary Eclipse fluorescence spectrophotometer. The interference of intracellular ions $\left(\mathrm{Cu}^{2+}, \mathrm{Ca}^{2+}, \mathrm{Mg}^{2+}\right.$ and $\left.\mathrm{Zn}^{2+}\right)$ on the measurement was negligible, which indicated a good photostability of IR787. MTT assay demonstrated that cell viability of human lung adenocarcinoma epithelial cell line A549 was not significantly affected by the use of the IR787 probe compared with the ICG probe. This result suggested that the IR787 probe was safe for in vitro cell imaging. In vitro NIR optical imaging experiments further revealed cellular uptake and strong intracellular NIR fluorescence of the IR787 probe in A549 cells. The excitation wavelength was $787 \mathrm{~nm}$ for IR787. Compared with the previously reported NIR fluorescent probe ICG, the IR787 NIR fluorescent probe had improved prospects for intracellular imaging. IR787 may play a pivotal role in the understanding cell biology, pharmacology and disease diagnosis.
\end{abstract}

\section{Introduction}

Biomedical imaging can be classified into magnetic resonance, near-infrared (NIR) and ionizing radiation (x-rays and $\gamma$-rays) based on electromagnetic spectrum used $(1,2)$. Due to the spectral characteristics, NIR fluorescent imaging is of interest for two main reasons: i) The auto-fluorescent background of biological cells can be significantly reduced under NIR excitation (3-5); and ii) greater tissue penetration can be realized owning to lower levels of NIR light scattering compared with visible light $(6,7)$. Therefore, NIR fluorescent imaging offers a unique approach for the visualization of physiological

Correspondence to: Dr Meng Wan, Department of Pharmacy, Nanjing First Hospital, Nanjing Medical University, 68 Changle Road, Nanjing, Jiangsu 210006, P.R. China

E-mail: wanmeng1985@sina.cn

Key words: near-infrared fluorescence imaging, fluorescent probe, indocyanine green, IR787, A549 cells activities in living biological systems, and has become a powerful tool for diagnostic and therapeutic applications in biology and medicine (8-11). A number of highly fluorescent probes based on the NIR region (600-900 nm) have been developed to date (12-15); however, only a few were approved for determining hepatic function, cardiac output and liver blood flow, as well as in ophthalmic angiography by the US Food and Drug Administration (16-18). As one of the NIR fluorescent probes authorized by the FDA, indocyanine green (ICG) shows no apparent cytotoxicity and few side effects, and can be widely applied to test hepatic output, cardiac function and to perform ophthalmologic angiography. ICG was also used as a potential photosensitizer (19-22). Nevertheless, its limitations such as low quantum yield, optical instability in vivo and unrestrained leakage in blood vessels have limited its applications (23). Numerous research groups are still attempting to design and synthesize improved ICG derivatives for in vivo imaging $(24,25)$.

The aim of the present study was to introduce a unique NIR fluorescent probe with high water solubility and good optical stability. The IR787 probe synthetized in the present study contained a sulfonic acid group, which was previously shown to improve water solubility when used in a biological (26), and tricarbocyanine dye, which was previously used as an NIR fluorescent dye due to its high extinction coefficient (27). The results of the current study suggest that the IR787 probe could provide good optical stability when it was applied to biological systems.

\section{Materials and methods}

Materials and instruments. Proton nuclear magnetic resonance $\left({ }^{1} \mathrm{H} \mathrm{NMR}\right)$ was conducted using the Bruker Avance ACF-300/500 MHz instrument (Bruker Corporation) in DMSO-d ${ }_{6}$ or $\mathrm{CDCl}_{3}$ (Tedia Company, Inc.). Tetramethylsilane (TMS, Sigma-Aldrich; Merck KGaA) was used as an internal standard. The ${ }^{1} \mathrm{H}$ NMR data were calculated based on TMS results and coupling constants ( $\mathrm{J}$ values) were expressed in $\mathrm{Hz}$. Molecular weight was obtained using a $6500 \mathrm{Q}-\mathrm{TOF}$ mass analyzer (Agilent Technologies, Inc.). Potassium 2,3,3-trimethyl-3H-indole-5-sulfonate (compound 1), 3-fluorobenzyl bromide (compound 2), 2-chloro-1-formyl-3-hy droxymethylenecyclohexene (compound 4) and ICG were purchased from Sigma Aldrich; Merck KGaA. The human lung adenocarcinoma epithelial cell line A549 was obtained from the American Type Culture Collection. Unless otherwise stated, all reagents were purchased from commercial suppliers 
and were used without further purification. Solvents were purified and dried by standard methods and distilled prior to use when necessary. All synthesis was performed under an inert atmosphere at $25^{\circ} \mathrm{C}$, magnetically stirred, and monitored by thin-layer chromatography (TLC) on silica gel GF-254 glass plates.

Synthesis of IR787. Synthesis of 1-(3-fluorobenzyl)-2,3,3-tr imethyl-3H-indol-1-ium-5-sulfonate. The synthetic route of IR787 was shown in Fig. 1. A mixture of compound 1 (1.24 g; $4.47 \mathrm{mmol})$, and compound $2(0.10 \mathrm{~g} ; 5.81 \mathrm{mmol})$ and toluene (Shanghai Chemical Reagents Institute Co., Ltd.; $12 \mathrm{ml}$ ) was refluxed with stirring under argon at $90^{\circ} \mathrm{C}$ for $14 \mathrm{~h}$. The reaction progress was monitored using TLC [EA/MeOH, 2:1 v/v; $\mathrm{Rf}$ value (retention factor) $=0.75]$. The resulting mixture was cooled down to $25^{\circ} \mathrm{C}$ and the resulting precipitate was isolated by vacuum filtration and then vacuum-concentrated. The crude residue obtained was purified by column chromatography on silica gel using ethyl acetate/methanol (Shanghai Chemical Reagents Institute Co., Ltd.), which yielded a pink solid, 1-(3-fluorobenzyl)-2,3,3-trimethyl -3H-indol-1-ium-5-sulfonate (compound 3; $1.31 \mathrm{~g}$; yield, $84.4 \%$ ).

Compound 3 (0.96 g; $2.76 \mathrm{mmol})$, compound 4 (0.24 g; $1.38 \mathrm{mmol}$ ) and anhydrous sodium acetate (Shanghai Chemical Reagents Institute Co. Ltd.; $0.23 \mathrm{~g} ; 2.76 \mathrm{mmol}$ ) were dissolved in $20 \mathrm{ml}$ acetic anhydride (Shanghai Chemical Reagents Institute Co., Ltd.). The solution was refluxed with stirring at $75^{\circ} \mathrm{C}$ for $4 \mathrm{~h}$. After the reaction, a green solid was produced and purified by column chromatography on silica gel using $\mathrm{DCM} / \mathrm{MeOH}\left(10: 1 \mathrm{v} / \mathrm{v} ; \mathrm{R}_{\mathrm{f}}=0.30\right)$ as an eluent. The resulting green solid was IR787, and its recovery rate was $33.1 \%(0.38 \mathrm{~g})$.

Absorption spectra. The absorption spectra of IR787 $(1 \mathrm{ml}$; $0.01 \mathrm{mM})$ and ICG $(1 \mathrm{ml} ; 0.01 \mathrm{mM})$ were measured with the UV-3600 UV visible spectrophotometer (Shimadzu Corporation) within the wavelength range of $600-900 \mathrm{~nm}$ at $25^{\circ} \mathrm{C}$ with methanol as the solvent.

Fluorescence spectra. IR787 and ICG were dissolved in methanol as stock solutions for fluorescence spectral analysis. The stock solutions were diluted to $0.01 \mathrm{mM}$ in methanol solution. The mixture was incubated for $3 \mathrm{~min}$ at $25^{\circ} \mathrm{C}$ before measurement and detected using fluorescence spectroscopy. Fluorescence intensity was measured at an excitation wavelength of $826 \mathrm{~nm}$.

Cell culture. Human lung adenocarcinoma epithelial cell line A549 was incubated routinely in RPMI-1640 medium supplemented with $10 \%(\mathrm{v} / \mathrm{v})$ fetal calf serum, $1 \%$ penicillin and $1 \%$ streptomycin in an atmosphere of $5 \% \mathrm{CO}_{2}$ and $95 \%$ air at $37^{\circ} \mathrm{C}$ in T25 cell culture flasks. Cells were split in 1:3 ratios at $80 \%$ confluence.

Cytotoxicity assay. The cytotoxicity of probe IR787 toward A549 cells was determined in 96-well microplates with ICG as control $(28,29)$. A549 cells were cultured as described above. Exponentially growing A549 cells were harvested and seeded in 96-well plates. After a $24 \mathrm{~h}$ incubation, cells were treated with probe concentrations from $10-120 \mu \mathrm{M}$ for $24 \mathrm{~h}$. The plates were incubated for $4 \mathrm{~h}$ after the addition of $10 \mu \mathrm{l}$ MTT solution
( $5 \mathrm{mg} / \mathrm{ml}$ ). The supernatant was subsequently removed and $100 \mu 1$ DMSO was added to dissolve the formazan crystals. The absorbance was measured with a plate reader (Victor ${ }^{3 \mathrm{TM}}$; PerkinElmer, Inc.) at a wavelength of $490 \mathrm{~nm}$. All the experiments were performed in quintuplicate, and data are presented as the mean $\pm \mathrm{SD}$.

Confocal imaging. The A549 cells were transferred to glass-bottom culture dishes and incubated with $10 \mu \mathrm{M}$ IR787 or $10 \mu \mathrm{M}$ ICG in FBS-free RPMI-1640 medium (Nanjing KeyGen Biotech Co., Ltd.) at $37^{\circ} \mathrm{C}$ for $30 \mathrm{~min}$. The medium was then removed, and A549 cells were washed thrice with PBS buffer ( $\mathrm{pH}$ 7.4). Florescent images were captured using a confocal microscope with an objective lens (magnification, x200). The excitation wavelengths were 787 and $805 \mathrm{~nm}$ for IR787 and ICG, respectively.

Statistical analysis. All experiments had at least three replicates for every tested group. Statistical analysis was performed using SPSS software (version 20.0; IBM Corp.). Cytotoxicity data and probe selectivity data were expressed as the mean \pm SD. Differences were tested for statistical significance using a t-test. $\mathrm{P}<0.05$ was considered to indicate a statistically significant difference.

\section{Results}

Characterization of IR787. The structure of IR787 was confirmed via ${ }^{1} \mathrm{H}-\mathrm{NMR}$ and MS. ${ }^{1} \mathrm{H}-\mathrm{NMR}(400 \mathrm{MHz}$, DMSO- $\left.\mathrm{d}_{6}\right): \delta(\mathrm{ppm})=1.73(\mathrm{~s}, 14 \mathrm{H}), 2.54-2.57(\mathrm{t}, \mathrm{J}=4 \mathrm{~Hz}, 4 \mathrm{H})$, $5.50(\mathrm{~s}, 4 \mathrm{H}), 6.36-6.40(\mathrm{~d}, \mathrm{~J}=14 \mathrm{~Hz}, 2 \mathrm{H}), 7.02-7.04(\mathrm{~d}, \mathrm{~J}=8 \mathrm{~Hz}$, 2H), 7.14-7.19 (m, 4H), 7.33-7.35 (d, J=8.4Hz, 2H), 7.38-7.44 $(\mathrm{m}, 4 \mathrm{H}), 7.625-7.629(\mathrm{~d}, \mathrm{~J}=1.6 \mathrm{~Hz}, 1 \mathrm{H}), 7.646-7.650(\mathrm{~d}, \mathrm{~J}=1.6 \mathrm{~Hz}$, $1 \mathrm{H}), 7.85(\mathrm{~s}, 2 \mathrm{H}), 8.23-8.26(\mathrm{~d}, \mathrm{~J}=14 \mathrm{~Hz}, 2 \mathrm{H})$. TOF-MS m/z: $829.3\left[\mathrm{M}-\mathrm{H}^{+}\right]^{-} .{ }^{1} \mathrm{H}$ NMR and MS spectra of IR787 were shown in Figs. 2 and 3.

Absorption and fluorescence spectra of IR787. The absorption and emission spectra of IR787 and ICG were examined in methanol solution. The maximal absorption wavelengths of IR787 and ICG were 787 and $783 \mathrm{~nm}$, respectively (Fig. 4). The results showed that IR787 exhibited a stronger blue excitation peak than ICG. The maximal emission wavelengths of IR787 and ICG were 826 and $832 \mathrm{~nm}$, respectively, and both exhibited a similar emission peak in methanol solution (Fig. 4). These results suggested that IR787 may be a promising potential NIR probe for biological systems.

Test for probe selectivity. Considering the complexity of the intracellular environment, an additional test was performed to determine whether $\mathrm{Cu}^{2+}, \mathrm{Ca}^{2+}, \mathrm{Mg}^{2+}$ and $\mathrm{Zn}^{2+}$ ions were potential interferents to the photostability of IR787. IR787 was used to determine whether the ions were potential interferents. The relative fluorescence intensity of IR787 $(1$ and $0.5 \mu \mathrm{M})$ at $787 \mathrm{~nm}$ in the absence or presence of $200 \mu \mathrm{M} \mathrm{Cu}^{2+}, \mathrm{Ca}^{2+}, \mathrm{Mg}^{2+}$ and $\mathrm{Zn}^{2+}$ ions in $40 \mathrm{mM}$ HEPES buffer solution at $\mathrm{pH} 6.50$ (excitation wavelength $=789 \mathrm{~nm}$ ) indicated that the effect of these ions on the measurement was negligible, and the probe had good photostability (Fig. 5). 
<smiles>CC1=Nc2ccc(S(=O)(=O)O)cc2C1(C)C</smiles>

Figure 1. Synthetic route of heptamethine cyanine dye IR787.

PROTON DMSO D:॥ nmrl 12

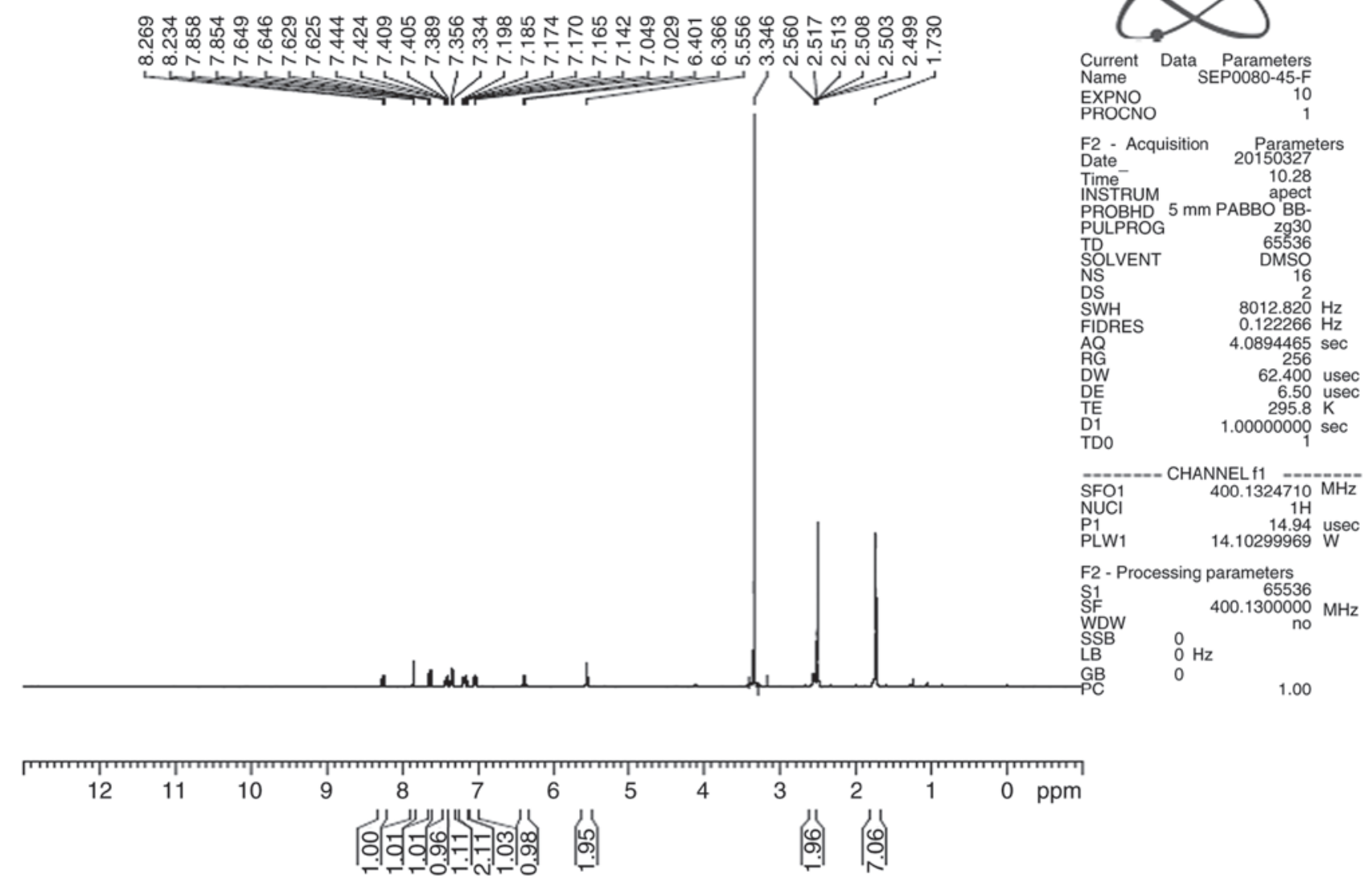

Figure 2. Proton nuclear magnetic resonance spectra of IR787.

Cytotoxicity assay. The biocompatibility of probes in living cells is an important consideration $(30,31)$. In the current study, the ICG and IR787 probes were evaluated in vitro to determine any cytotoxicity in A549 cells using the MTT method. The MTT assay was performed with probe concentrations of $10-120 \mu \mathrm{M}$. The results indicated that compared with ICG treatment, the viability of A549 cells treated with IR787 was not significantly different at any treatment concentration. Furthermore, A549 cells retained $>75 \%$ of the control group viability even when treated with $120 \mu \mathrm{M}$ ICG or IR787 for $24 \mathrm{~h}$ (Fig. 6). Cytotoxicity assay results revealed that the viability of A549 cells was not significantly affected by the probes used in the current study, indicating that the IR787 probe was safe for in vitro cell imaging. 


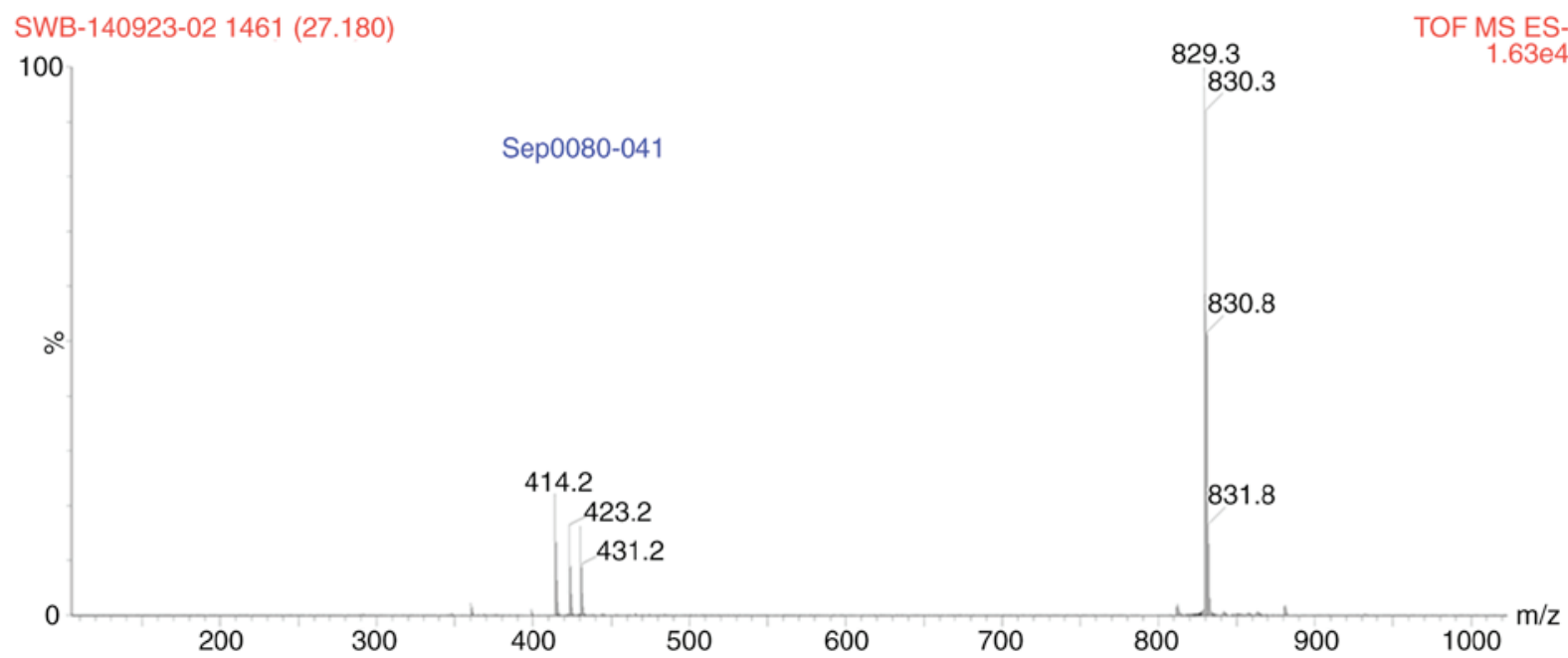

Figure 3. Mass spectrometry analysis of IR787.
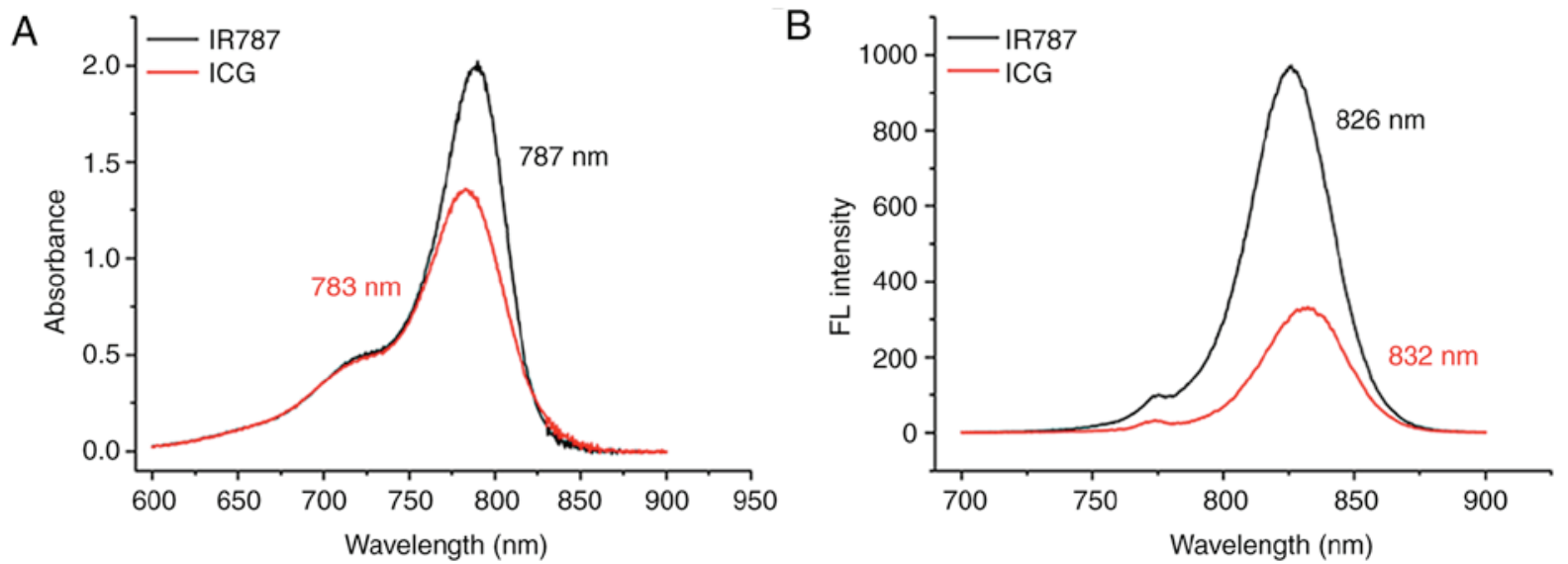

Figure 4. Absorption and emission spectra of IR787 examined in methanol solution. (A) Absorption and (B) emission spectra of $10 \mu \mathrm{M}$ IR787 and $10 \mu \mathrm{M}$ ICG in methanol solution. FL, fluorescence; ICG, indocyanine green.

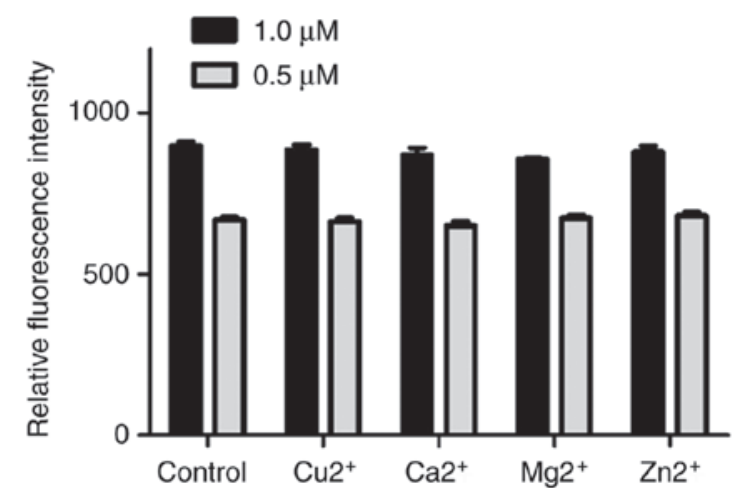

Figure 5. Fluorescence intensity of 1 and $0.5 \mu \mathrm{M}$ IR787 at $789 \mathrm{~nm}$ in the absence or presence of $200 \mu \mathrm{M} \mathrm{Cu}^{2+}, \mathrm{Ca}^{2+}, \mathrm{Mg}^{2+}$ and $\mathrm{Zn}^{2+}$ ions in a buffer solution at pH 6.50 (excitation wavelength=789 $\mathrm{nm}$ ).

In vitro cell imaging. Due to the low cytotoxicity of IR787, confocal fluorescence imaging was performed to study its applicability for living cells. A549 cells were inoculated in $10 \mu \mathrm{M}$ IR787 or ICG for $30 \mathrm{~min}$. The total time of fluorescence stability (Fig. 7) was $40 \mathrm{~min}$. The distributions

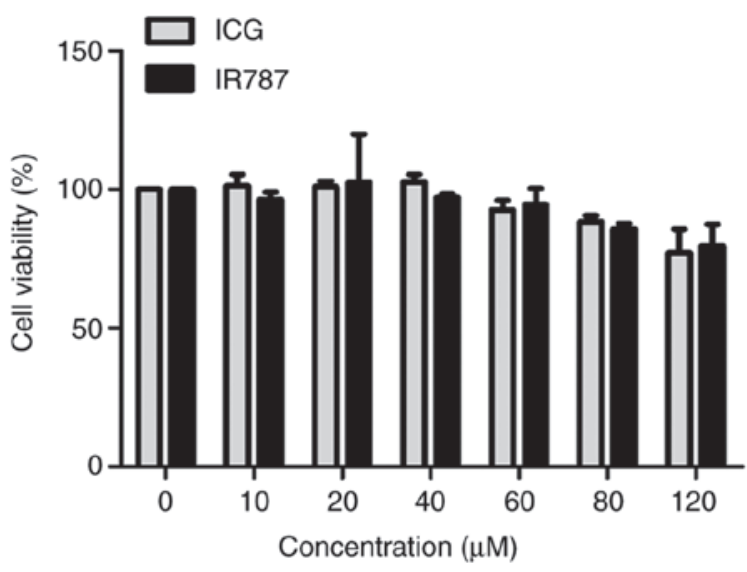

Figure 6. Viability of A549 cells incubated with $0-120 \mu \mathrm{M}$ IR787 and ICG. ICG, indocyanine green.

of IR787 and ICG in A549 cells were observed under a fluorescence microscope. As shown in Fig. 7A and C, IR787 and ICG could permeate into the membrane with varying fluorescence intensities. The present results suggested that 
A

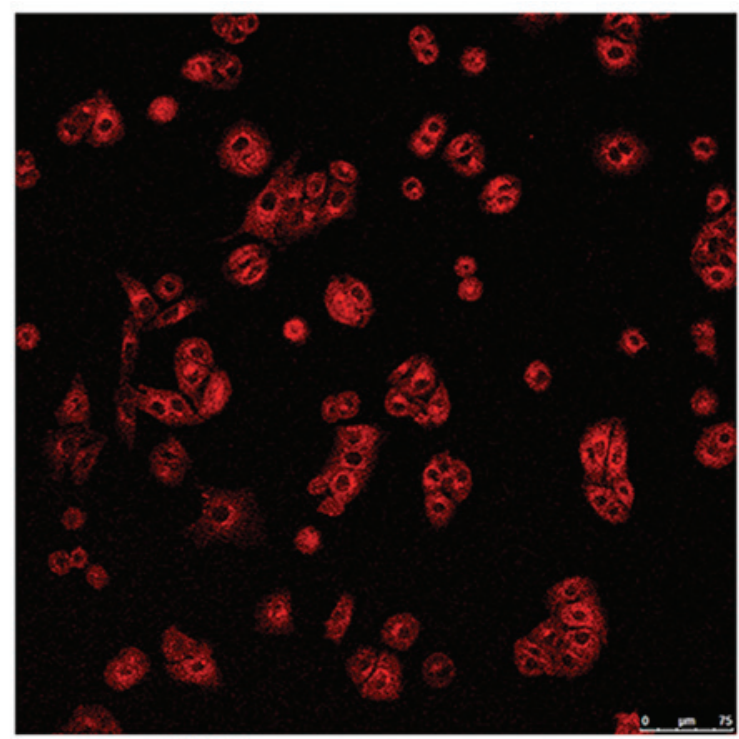

C

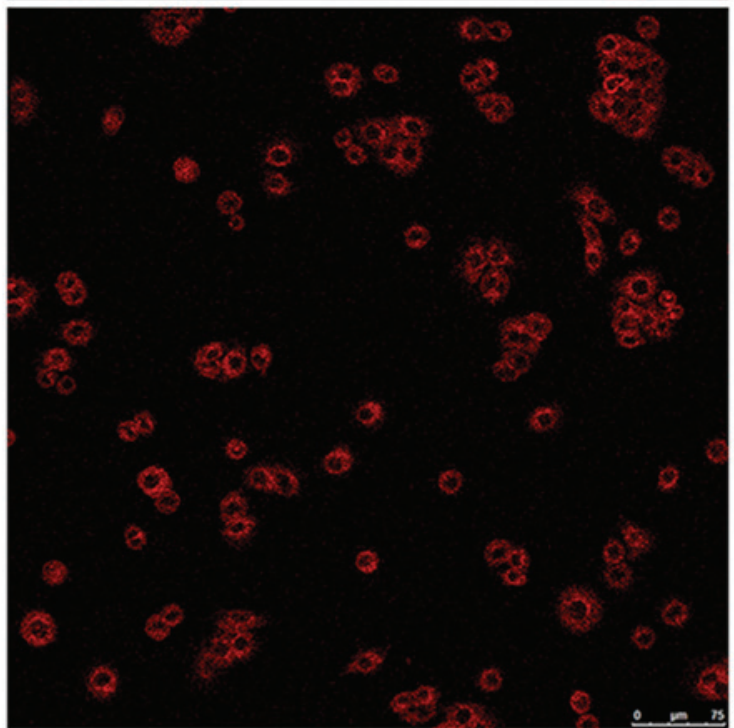

B

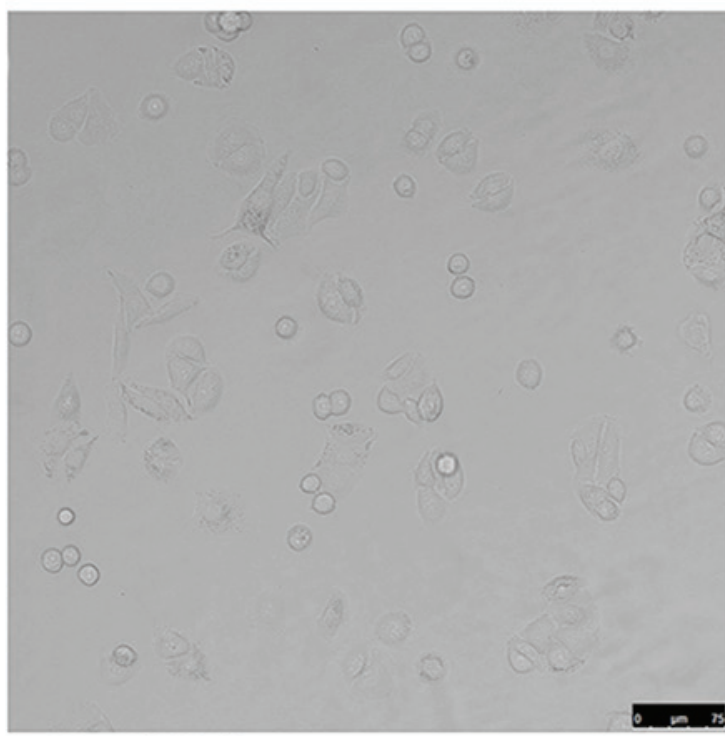

D

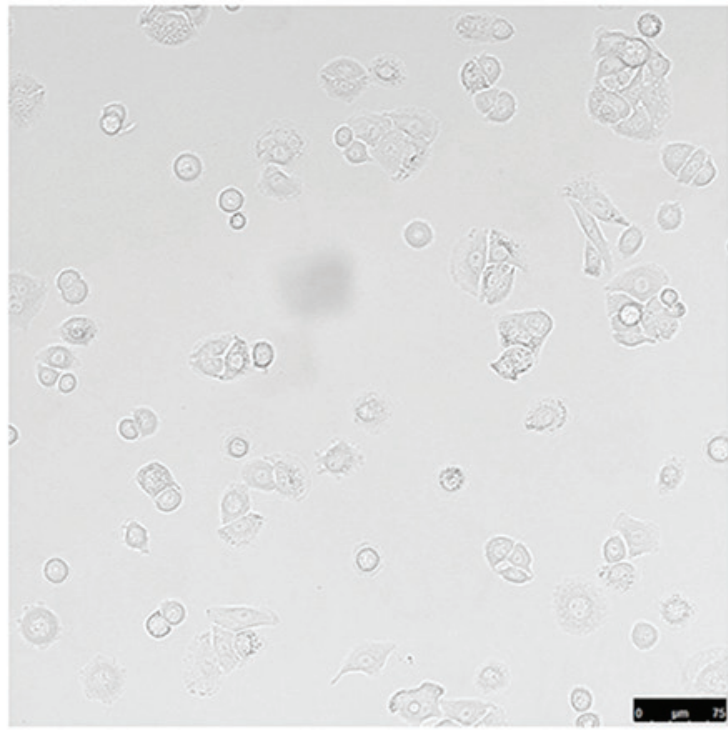

Figure 7. Confocal fluorescence images of living A549 cells (magnification x200). (A) Confocal fluorescence and (B) bright field images of living A549 cells incubated with $10 \mu \mathrm{M}$ IR787 at $37^{\circ} \mathrm{C}$ for $30 \mathrm{~min}$. (C) Confocal fluorescence and (D) bright field images of living A549 cells incubated with $10 \mu \mathrm{M}$ ICG at $37^{\circ} \mathrm{C}$ for $30 \mathrm{~min}$. ICG, indocyanine green.

the IR-789 had excellent membrane permeability and good photostability.

\section{Discussion}

The application of NIR fluorescent probes to imaging techniques allows the real-time in vivo cell imaging. In the present study, a novel NIR fluorescent probe IR787 was designed, synthesized and its cytotoxicity, optical features and applicability in living A547 cell imaging were characterized. The two-step synthetic process of IR787 makes its large-scale production possible. The stronger excitation and emission characteristics showed that IR787 had improved optical properties compared with ICG. The IR787 probe, a derivate of heptamethine indocyanines, may exhibit a good cytoplasmic localization due to intracellular accumulation and membrane permeability (32). MTT assay results suggested that IR787 had low cytotoxic effects and the viability of A549 cells was $>75 \%$ even when incubated with $120 \mu \mathrm{M}$ IR787. Further experiments demonstrated that IR787 could effectively test in living cells.

In conclusion, the current study successfully developed a novel and simple NIR fluorescent probe for living cell imaging. Compared with the previously reported NIR fluorescent probe ICG, the IR787 probe had improved prospects for intracellular imaging. IR787 is hoped to play an important role in understanding cell biology, pharmacology, and disease diagnosis. In future work, this probe will be used as a fluorescent probe with specific chemically-conjugated ligands to improve its selectivity and broaden the application potential.

\section{Acknowledgements}

Not applicable.

\section{Funding}

Not applicable. 


\section{Availability of data and materials}

All data generated or analyzed during this study are included in this published article.

\section{Authors' contributions}

MW contributed to the conception, design, writing and revision of the manuscript. YZ and JZ contributed to the acquisition of data and the analysis of data.

\section{Ethics approval and consent to participate}

Not applicable.

\section{Patient consent for publication}

Not applicable.

\section{Competing interests}

The authors declare that they have no competing interests.

\section{References}

1. Pansare VJ, Hejazi S, Faenza WJ and Prud'Homme RK: Review of long-wavelength optical and NIR imaging materials: Contrast agents, fluorophores and multifunctional nano carriers. Chem Mater 24: 812-827, 2012.

2. Chan $\mathrm{M}$ and Almutairi A: Nanogels as imaging agents for modalities spanning the electromagnetic spectrum. Mater Horiz 3: 21-40, 2015.

3. Galanzha EI, Shashkov EV, Tuchin VV and Zharov VP: In vivo multispectral, multiparameter, photoacoustic lymph flow cytometry with natural cell focusing, label-free detection and multicolor nanoparticle probes. Cytometry A 73A: 884-894, 2008.

4. Dip F, Roy M, Lo Menzo E, Simpfendorfer C, Szomstein S and Rosenthal RJ: Routine use of fluorescent incisionless cholangiography as a new imaging modality during laparoscopic cholecystectomy. Surg Endosc 29: 1621-1626, 2015.

5. Kiviharju K, Salonen K, Moilanen U, Meskanen E, Leisola M and Eerikäinen T: On-line biomass measurements in bioreactor cultivations: Comparison study of two on-line probes. J Ind Microbiol Biotechnol 34: 561-566, 2007.

6. Zhang X, Gu YQ and Chen HY: Synthesis of biocompatible near infrared fluorescence Ag2S quantum dot and application in bioimaging. J Innov Optic Health Sci 7: 1350059, 2014.

7. Sampaio PN, Sales KC, Rosa FO, Lopes MB and Calado CR: High-throughput FTIR-based bioprocess analysis of recombinant cyprosin production. J Ind Microbiol Biotechnol 44: 49-61, 2017.

8. Yuan L, Lin W, Zhao S, Gao W, Chen B, He L and Zhu S: A unique approach to development of near-infrared fluorescent sensors for in vivo imaging. J Am Chem Soc 134: 13510-13523, 2012.

9. Jumarie C, Séïde M, Marcocci L, Pietrangeli P and Mateescu MA: Diamine oxidase from white pea (Lathyrus sativus) combined with catalase protects the human intestinal caco-2 cell line from histamine damage. Appl Biochem Biotechnol 182: 1171-1181, 2017.

10. Wang R, Yu C, Yu F, Chen L and Yu C: Molecular fluorescent probes for monitoring $\mathrm{pH}$ changes in living cells. TrAC Trends Anal Chem 29: 1004-1013, 2010.

11. Luan LQ, Fang WJ, Liu W, Tian MG, Ni YX, Chen X, Yu XQ, He J, Yang Y and Li XG: 4-tert-butylphenoxy substituted phthalocyanine with RGD motif as highly selective one-photon and two-photon imaging probe for mitochondria and cancer cell. J Porphyrins Phthalocyanines 20: 1-10, 2016.

12. Xing J, Zhou G, Sun C, Zhang H, Chen B, Zong X, Cai J and Ji M: Synthesis and characterization of a novel near-infrared fluorescent probe for applications in imaging a549 cells. Biotechnol Lett 38: 1-6, 2016.
13. Kiyose K, Kojima H, Urano Y and Nagano T: Development of a ratiometric fluorescent zinc ion probe in near-infrared region, based on tricarbocyanine chromophore. J Am Chem Soc 128: 6548-6549, 2006.

14. Sun C, Cai J, Chen J, Wu Y, Wang P, Zhou G, Zong X, Chen B, Lv Y and Ji M: The synthesis of a novel near-infrared fluorescent probe and its application in imaging of living cells. Appl Biochem Biotechnol 175: 1644-1650, 2015.

15. Sun C, Wu Y, Cai J, Wang P, Zong X, Zhou G, Li L and Ji M: Synthesis of a near-infrared fluorescent probe and its application in imaging of MCF-7 cells. Biotechnol Lett 36: 1203-1207, 2014.

16. Liu K, Shang H, Meng F, Liu Y and Lin W: A novel near-infrared fluorescent platform with good photostability and the application for a reaction-based $\mathrm{Cu}(2+)$ probe in living cells. Talanta 147: 193-198, 2016.

17. Li C, Greenwood TR, Glunde K and Bhujwalla ZM: Synthesis and characterization of glucosamine-bound near-infrared probes for optical imaging. Org Lett 8: 3623-3626, 2006.

18. Luo S, Zhang E, Su Y, Cheng T and Shi C: A review of NIR dyes in cancer targeting and imaging. Biomaterials 32: 7127-7138, 2011.

19. Lim SY, Hong KH, Kim DI, Kwon H and Kim HJ: Tunable heptamethine-azo dye conjugate as an NIR fluorescent probe for the selective detection of mitochondrial glutathione over cysteine and homocysteine. J Am Chem Soc 136: 7018-7025, 2014.

20. Ziemiński K and Kowalskawentel M: Effect of different sugar beet pulp pretreatments on biogas production efficiency. Appl Biochem Biotechno 181: 1211-1227, 2017.

21. Walther CG, Whitfield R and James DC: Importance of interaction between integrin and actin cytoskeleton in suspension adaptation of CHO cells. Appl Biochem Biotechnol 178: 1286-1302, 2016.

22. El-Daly SM, Gamal-Eldeen AM, Abo-Zeid MA, Borai IH, Wafay HA and Abdel-Ghaffar AR: Photodynamic therapeutic activity of indocyanine green entrapped in polymeric nanoparticles. Photodiagnosis Photodyn Ther 10: 173-185, 2013.

23. Funayama T, Sakane M, Abe T, Hara I, Ozeki E and Ochiai N: Intraoperative near-infrared fluorescence imaging with novel indocyanine green-loaded nanocarrier for spinal metastasis: A preliminary animal study. Open Biomed Eng J 6: 80-84, 2012.

24. Shafirstein G, Bäumler W, Hennings LJ, Siegel ER, Ran F, Moreno MA, Webber J, Jackson C and Griffin RJ: Indocyanine green enhanced $\mathrm{n}$ ear infrared laser treatment of murine mammary carcinoma. Int J Cancer 130: 1208-1215, 2012.

25. Schubert GA, Barth M and Thomé C: The use of indocyanine green videography for intraoperative localization of intradural spinal tumors. Spine 35: E212-E217, 2010.

26. Zhou LC, Zhao GJ, Liu JF, Han KL, Wu YK, Peng XJ and Sun MT: The charge transfer mechanism and spectral properties of a near-infrared heptamethine cyanine dye in alcoholic and aprotic solvents. J Photochem Photobiol Chem 187: 305-310, 2007.

27. Tang B, Liu X, Xu K, Huang H, Yang G and An L: A dual near-infrared $\mathrm{pH}$ fluorescent probe and its application in imaging of HepG2 cells. Chem Commun (Camb) 41: 3726-3728, 2007.

28. Seidl K and Zinkernagel AS: The MTT assay is a rapid and reliable quantitative method to assess staphylococcus aureus induced endothelial cell damage. J Microbiol Methods 92: 307-309, 2013.

29. Skehan P, Storeng R, Scudiero D, Monks A, McMahon J, Vistica D, Warren JT, Bokesch H, Kenney S and Boyd MR: New colorimetric cytotoxicity assay for anticancer-drug screening. J Natl Cancer Inst 82: 1107-1112, 1990.

30. Funayama T, Sakane M, Abe T and Ochiai N: Photodynamic therapy with indocyanine green injection and near-infrared light irradiation has phototoxic effects and delays paralysis in spinal metastasis. Photomed Laser Surg 30: 47-53, 2012.

31. Liang Y, Gao W, Peng X, Deng X, Sun C and He B: Near infrared light responsive hybrid nanoparticles for synergistic therapy. Biomaterials 100: 76-90, 2016.

32. Nakayama A, Bianco AC, Zhang CY, Lowell BB and Frangioni JV: Quantitation of brown adipose tissue perfusion in transgenic mice using near-infrared fluorescence imaging. Mol Imaging 2: 37-49, 2003.

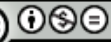

This work is licensed under a Creative Commons Attribution-NonCommercial-NoDerivatives 4.0 International (CC BY-NC-ND 4.0) License. 